\title{
SEROLOGICAL AND PROTECTIVE-ANTIBODY RESPONSES OF RABBITS TO LEPTOSPIRAL ANTIGENS
}

\author{
B. AdLer AND S. FAINE \\ Department of Microbiology, Monash University Medical School, Alfred Hospital, \\ Prahran, 3181 Victoria, Australia
}

AlKaline extraction of leptospires (Hindle and White, 1933-34) produced a lipopolysaccharide (LPS) antigen designated "F4" (Faine, Adler and Palit, 1974) that sensitised sheep erythrocytes to haemagglutination (HA) by homologous rabbit antiserum, and was involved in the immune response in leptospirosis (Faine, Adler and Ruta, 1974).

The present work was part of an investigation of the immune response elicited by this antigen, and its role, if any, in immunity to leptospiral infection. The results provide important points of contrast and similarity in relation to the studies of Adler and Faine (1978) on human leptospirosis.

\section{METHODS AND MATERIALS}

Leptospires, antigens and serological methods. The strain of Leptospira interrogans serovar pomona, the cultural and counting methods and the microscopic agglutination (MA) test were as described by Adler and Faine (1976). Antigen (F4) was extracted and used in HA tests as described by Faine, Adler and Palit (1974), and the methods of Adler and Faine (1978) were used for absorbing sera with leptospires or F4, and for fractionating sera on sucrose density gradients.

Animals. New Zealand White rabbits of either sex were inoculated intravenously via the marginal ear vein with $5 \mathrm{ml}$ of viable leptospiral culture in Korthof's medium containing rabbit serum $10 \%$. Rabbits were inoculated intramuscularly by means of two injections, each consisting of $1 \mathrm{ml}$ of Freund's incomplete adjuvant and an equal volume of a saline suspension of leptospires concentrated by centrifugation.

Further rabbits were immunised with an emulsion consisting of equal volumes of Freund's complete adjuvant and a solution of $\mathrm{F} 4$ antigen in saline $(1.2 \mathrm{mg}$ per ml); each rabbit received $0 \cdot 1-\mathrm{ml}$ volumes intradermally in 20 sites on the shaved back and flanks. Rabbits were bled from the marginal ear vein at intervals after immunisation. Hamster protection tests were performed as described by Adler and Faine (1978) with $0 \cdot 1-\mathrm{ml}$ doses of serum unless otherwise stated.

In-vitro effect of serum on the viability of leptospires. Serum was diluted in veronalbuffered saline, $p \mathrm{H} 7 \cdot 2$, in microtitre trays. To each well was added a volume of fresh guinea-pig serum as a source of complement, together with a volume of leptospiral culture. Trays were incubated at $30^{\circ}$ or $37^{\circ} \mathrm{C}$ for various times, after which a loopful from each well was removed to count the proportion of viable (motile) leptospires by darkfield microscopy.

Indirect fluorescent-antibody test. Washed leptospires were air-dried on a glass slide, fixed by immersion in ethanol for $15 \mathrm{~s}$, and air-dried again. The slide was covered with undiluted rabbit antiserum and left for $30 \mathrm{~min}$. at room temperature in a moist atmosphere. It was then washed for $30 \mathrm{~min}$. with PBS. A drop of sheep anti-rabbit serum conjugated

Received 21 Nov. 1977; accepted 7 Feb. 1978. 
with fluorescein iso-thiocyanate (Wellcome Reagents) was placed on the preparation and left for $30 \mathrm{~min}$. as above. Each preparation was then washed in phosphate-buffered saline (PBS), air-dried, mounted in PBS-buffered glycerol and examined by means of a microscope equipped with a Zeiss KP500 filter and 470- and 530-nm barrier filters, and illuminated with a quartz-halogen lamp.

\section{RESULTS}

The serological response of rabbits inoculated with viable leptospires

The rabbit agglutinin and F4-antibody responses to viable serovar pomona injected intravenously were compared with the responses to a similar dose injected intramuscularly with Freund's incomplete adjuvant (fig. 1). Of the
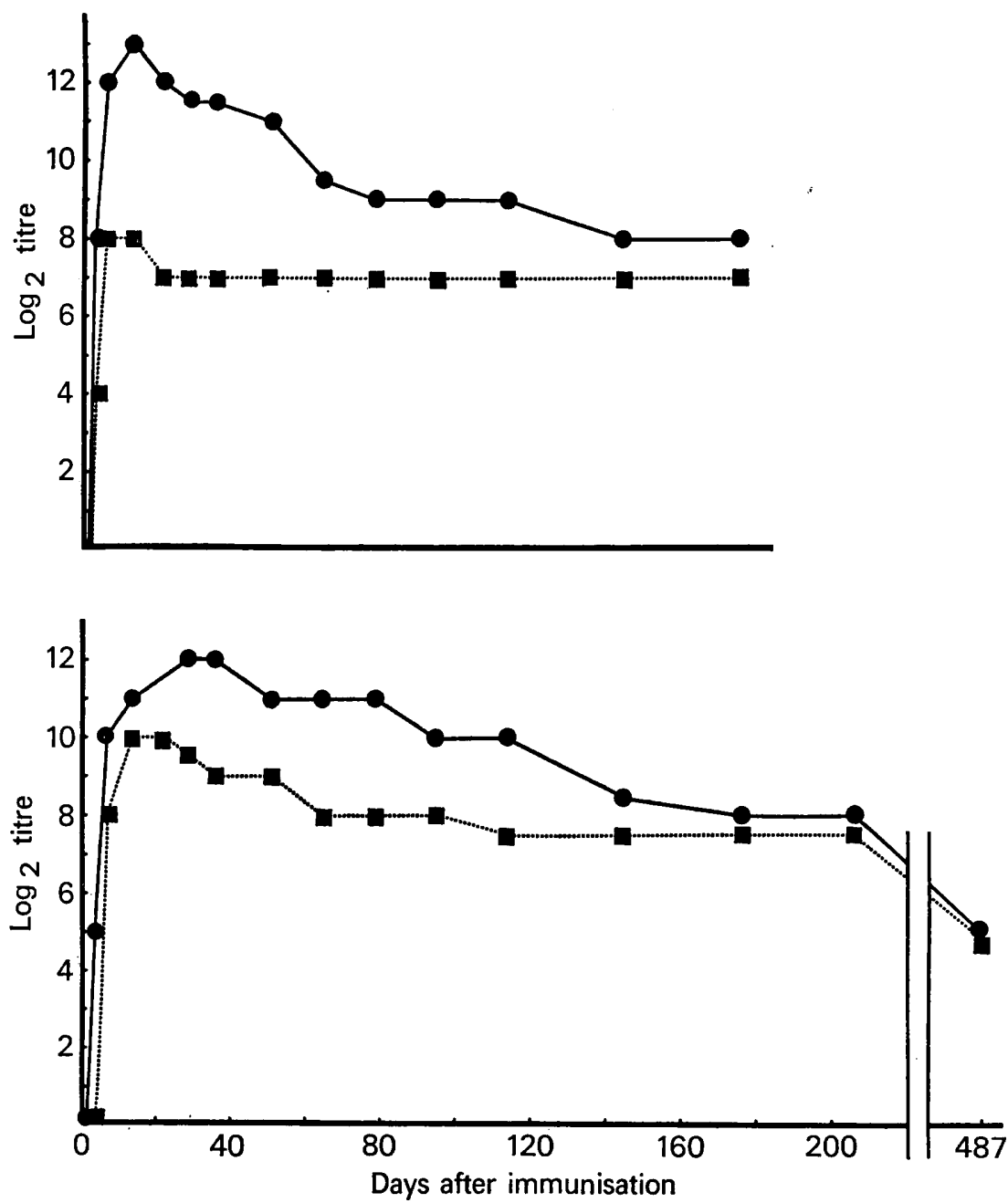

FIG. 1.-Agglutinin (- with leptospires of serovar pomona intravenously (above) or intramuscularly, with adjuvant (below). 
two methods of immunisation, the intravenous produced the more rapid appearance of both types of antibody, and the intramuscular elicited the higher titres of F4 antibody; the two methods produced similar agglutinin titres (fig. 1).

The IgM content and IgG content of sera from rabbits immunised as described above were examined by fractionation on sucrose density gradients. The results (fig. 2) showed that both methods of immunisation produced similar agglutinin responses, although IgG agglutinin appeared later and persisted longer after intramuscular immunisation than after intravenous immunisation. However, the intravenous method elicited F4 antibodies that were exclusively
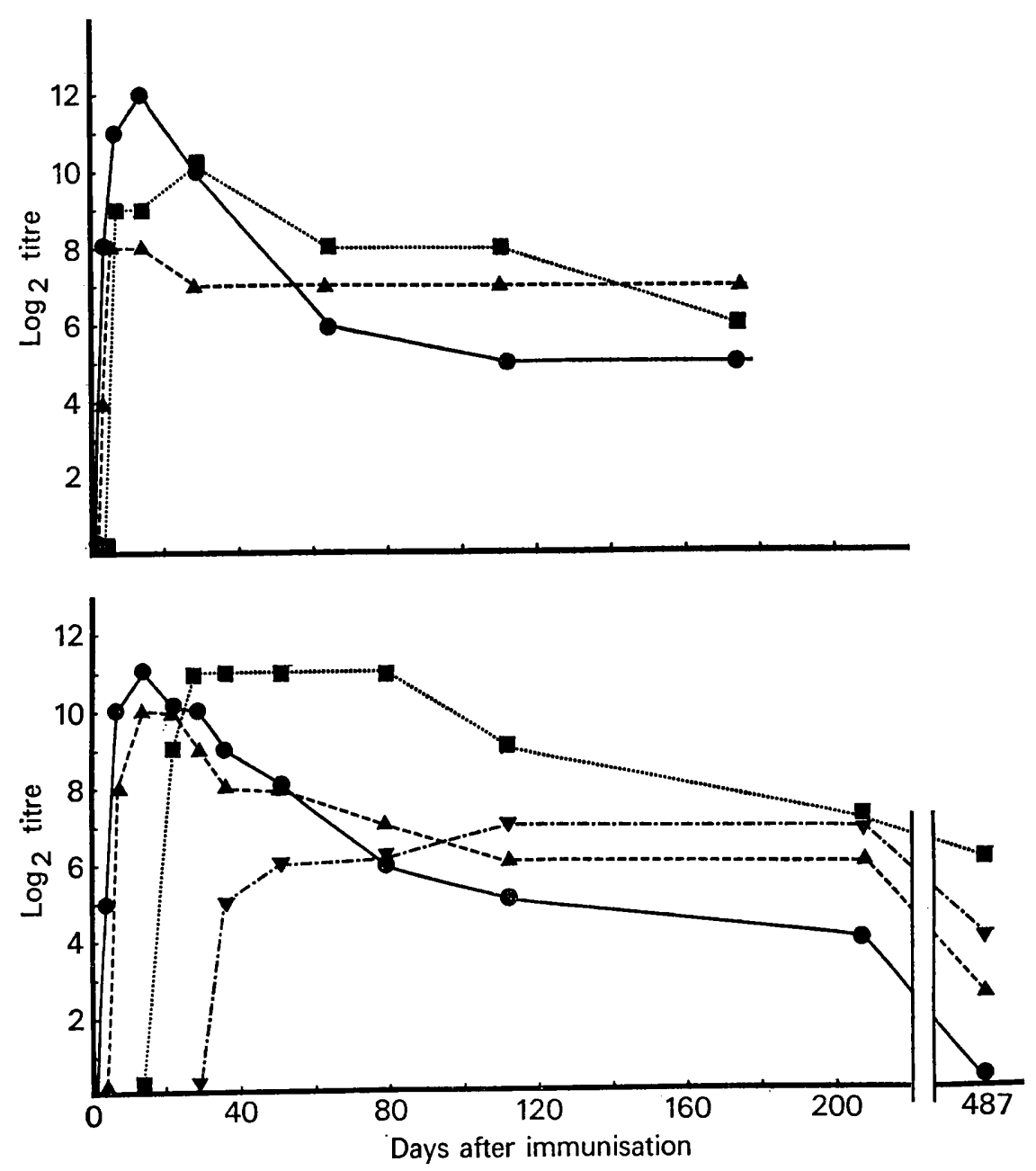

FIG. 2.-IgM agglutinins ( and IgG F4 antibody $(\nabla-\cdot-\cdot \nabla)$ in rabbits immunised with leptospires of serovar pomona intravenously (above) or intramuscularly, with adjuvant (below). Note that F4 antibodies of the IgG class were not found after intravenous immunisation.

J. MED. MICROBIOL.-VOL. 11 (1978) 
in the IgM class, whereas the intramuscular method produced F4 antibodies in both the IgM class and the IgG class (fig. 2).

\section{The serological response of rabbits inoculated with F4 antigen}

Antibody could not be detected in rabbits after either a single intravenous injection of $10 \mu \mathrm{g}-5 \mathrm{mg}$ of soluble $\mathrm{F} 4$ or three intravenous injections of $1.0 \mathrm{mg}$ at weekly intervals, although it is known that the antigen adsorbed on erythrocytes is antigenic (Faine, Adler and Palitt, 1974). However, agglutinating antibodies and $\mathrm{F} 4$ antibodies were produced as a result of the intradermal injection into 20 sites of a total of $1.2 \mathrm{mg}$ of F4 antigen emulsified in Freund's complete adjuvant (fig. 3). The F4 antibodies were of a higher titre and persisted longer than the agglutinins, but both types of antibody were found solely in the IgM fraction.

\section{Relationship between agglutinins and F4 antibodies}

Erythrocytes sensitised with F4 antigen were able to absorb F4 antibodies but not agglutinins from antiserum against whole leptospires of serovar pomona. The results were the same, regardless of whether the antibodies were in the IgM or IgG class (table). Absorption of similar antiserum with leptospires removed both agglutinin and F4 antibody. Absorption of F4 antiserum with either F4-sensitised erythrocytes or whole leptospires removed all F4 antibodies (table). Thus, 306 days after immunisation (fig. 3), F4 antiserum with no agglutinating activity still contained antibodies that combined with, and were removed by, whole leptospires.

In order to confirm that non-agglutinating F4 antibodies are capable of combining with leptospires, a preparation of fixed leptospires was treated with undiluted F4 antiserum (agglutinin titre, 0; F4 antibody titre, 256) and then with fluorescein conjugated anti-rabbit globulin. The leptospires exhibited

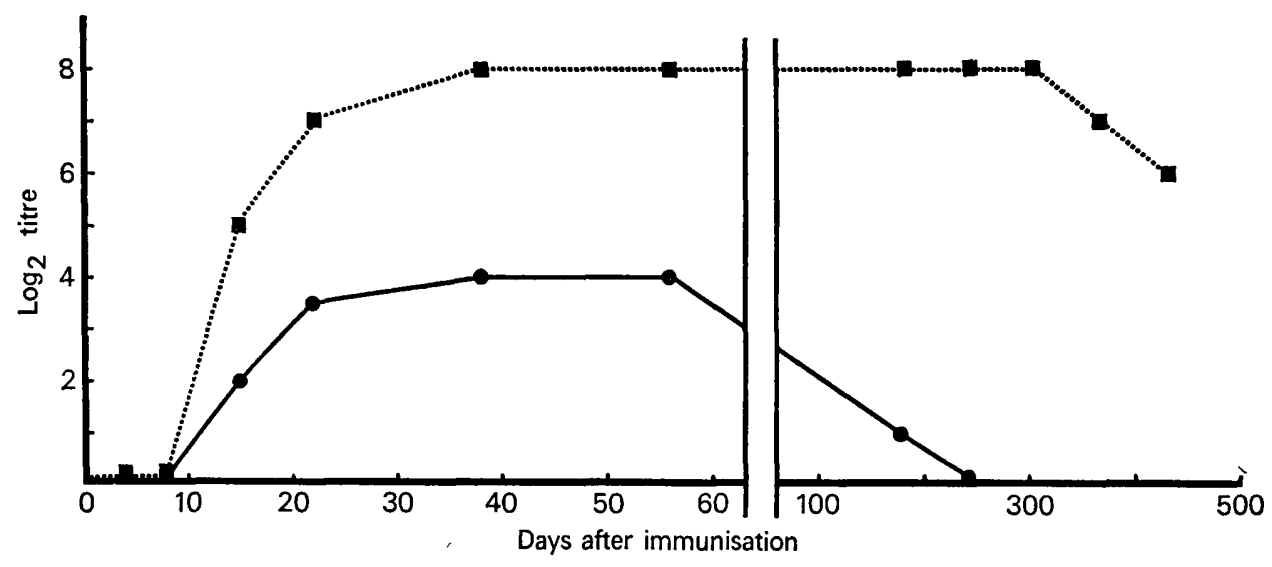

Fig. 3.-Agglutinin (@with F4 antigen of serovar pomona in Freund's complete adjuvant. A total of $1.2 \mathrm{mg}$ of F4 antigen was injected into 20 sites on the shaved flanks. 
TABLE

The use of whole cells (WC) or F4 antigen of serovar pomona to absorb rabbit antisera prepared by immunisation with WC or F4

\begin{tabular}{|c|c|c|c|c|c|c|}
\hline \multirow{2}{*}{$\begin{array}{c}\text { Antiserum } \\
\text { against }\end{array}$} & \multirow{2}{*}{$\begin{array}{c}\text { Route of } \\
\text { immunisation }\end{array}$} & \multicolumn{2}{|c|}{$\begin{array}{l}\text { Titre of antibody before } \\
\text { absorption }\end{array}$} & \multirow{2}{*}{$\begin{array}{l}\text { Antiserum } \\
\text { absorbed } \\
\text { with }\end{array}$} & \multicolumn{2}{|c|}{$\begin{array}{l}\text { Titre of antibody after } \\
\text { absorption }\end{array}$} \\
\hline & & Agglutinin & F4 antibody & & Agglutinin & F4 antibody \\
\hline wC & Intravenous & $\begin{array}{l}4096 \\
4096\end{array}$ & $\begin{array}{l}1024 \\
1024\end{array}$ & $\begin{array}{l}\text { WC } \\
\text { F4 }\end{array}$ & $\begin{array}{r}0 \\
2048\end{array}$ & $\begin{array}{l}\mathbf{0} \\
\mathbf{0}\end{array}$ \\
\hline $\mathrm{WC}^{*}$ & Intramuscular & $\begin{array}{l}2048 \\
2048\end{array}$ & $\begin{array}{l}1024 \\
1024\end{array}$ & $\begin{array}{l}\text { WC } \\
\text { F4 }\end{array}$ & $\begin{array}{r}0 \\
1024\end{array}$ & $\begin{array}{l}\mathbf{0} \\
\mathbf{0}\end{array}$ \\
\hline $\mathrm{WC} \dagger$ & Intramuscular & $\begin{array}{l}512 \\
512\end{array}$ & $\begin{array}{l}128 \\
128\end{array}$ & $\begin{array}{l}\text { WC } \\
\text { F4 }\end{array}$ & $\begin{array}{r}0 \\
512\end{array}$ & $\begin{array}{l}0 \\
0\end{array}$ \\
\hline F4 (38) & Intradermal & $\begin{array}{l}16 \\
16\end{array}$ & $\begin{array}{l}256 \\
256\end{array}$ & $\begin{array}{l}\text { WC } \\
\text { F4 }\end{array}$ & $\begin{array}{l}0 \\
0\end{array}$ & $\begin{array}{l}0 \\
0\end{array}$ \\
\hline F4 (306) & Intradermal & $\begin{array}{l}0 \\
0\end{array}$ & $\begin{array}{l}256 \\
256\end{array}$ & $\begin{array}{l}\text { WC } \\
\text { F4 }\end{array}$ & $\begin{array}{l}0 \\
0\end{array}$ & $\begin{array}{l}0 \\
0\end{array}$ \\
\hline
\end{tabular}

* The antibodies examined were in the IgM class.

$\dagger$ The antibodies examined were in the IgG class.

The numbers in parenthesis indicate the intervals (days) between immunisation and the collection of the serum.

Agglutinin and F4 antibody were measured by the microscopic agglutination test and passive haemagglutination test respectively.

strong fluorescence that was only slightly less intense than that observed with whole leptospire antiserum (agglutinin titre, 1024), and that was not seen with pre-immunisation serum.

\section{In-vitro effect of F4 antiserum on leptospires}

Serovar pomona F4 antiserum with a high F4 antibody titre 306 days after immunisation (fig. 3) did not immobilise homologous leptospires; the tests were carried out with undiluted and diluted serum, with and without added fresh guinea-pig serum as a source of complement, and with incubation at $30^{\circ}$ and $37^{\circ} \mathrm{C}$ for up to $8 \mathrm{~h}$. F4 antiserum with agglutinating antibody, 38 days after immunisation (fig. 3), killed and immobilised homologous leptospires in the presence of complement. After $60 \mathrm{~min}, 92 \%$ of the cells in a suspension containing $10^{7}$ leptospires per $\mathrm{ml}$ were non-motile. Immobilisation did not occur in the absence of complement.

\section{Passive protection of hamsters with rabbit antisera}

The capacity of rabbit antisera to protect hamsters from acute infection with $4 \times 10^{8}$ leptospires (serovar pomona) is shown in fig. 4. The level of protective antibody closely paralleled the agglutinin titre. The relative amounts of IgM and IgG involved did not affect this finding. 

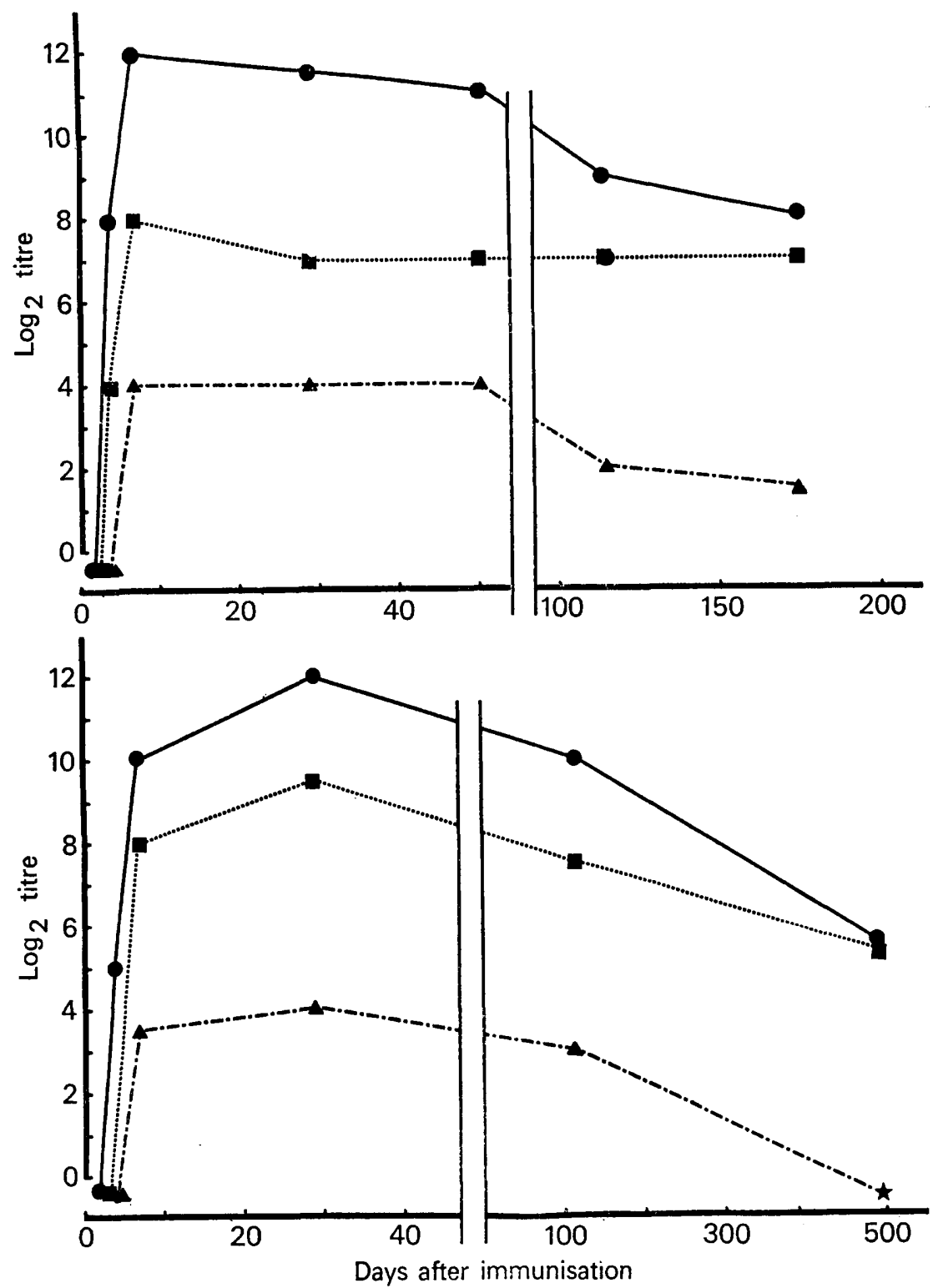

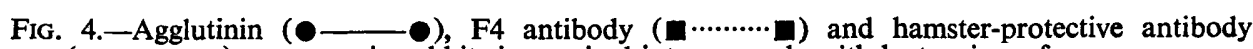
$(\Delta-\cdots-\Delta)$ responses in rabbits immunised intravenously with leptospires of serovar pomona (above) or intramuscularly, with adjuvant (below). $\star=$ The standard dose $(0.1 \mathrm{ml})$ of serum did not protect hamsters, but protection could still be demonstrated with $0 \cdot 2 \mathrm{ml}$.

The protective role of F4 antibodies in serovar pomona-F4 antiserum was tested in hamsters. Amounts of $0.2 \mathrm{ml}$ of antiserum taken 8, 38, 56, 182, 306 and 367 days after immunisation (fig. 3) did not protect hamsters from acute infection. Volumes of $0.4 \mathrm{ml}$ of serum (agglutinin titre, 16; F4 antibody titre, 256) taken on days 38 and 56 protected, but $0.4-\mathrm{ml}$ volumes of serum 
taken on days $8,182,306$ and 367 did not; it should be noted that the F4 antibody titres in the non-protective sera taken on days 182 and 306 were similar to those in the protective sera taken on days 38 and 56. Thus, F4 antiserum protected hamsters from infection only if it contained agglutinin.

\section{DisCUSSION}

The immunoglobulin classes in which the $\mathrm{F} 4$ antibody lay depended on the method and route of immunisation and on the form in which the F4 antigen was presented. To evoke the production of IgG-class F4 antibodies it was necessary to present the antigen in a particulate form, with adjuvant. Soluble F4 antigen with adjuvant, or F4 as a component of whole leptospires without adjuvant, elicited only IgM-class F4 antibodies, as did intravenous injection of whole leptospires. However, intramuscular injection of antigen with adjuvant gave rise to both IgM- and IgG-class F4 antibodies.

Purified F4 antigen was not immunogenic when injected in soluble form without adjuvant. When injected intradermally with adjuvant it stimulated the production of F4 antibodies detectable by HA, and of low levels of agglutinins; both antibodies were confined to the IgM class. By contrast, injection of whole leptospires by any route always stimulated IgG agglutinins as well as IgM agglutinins. The F4 antibodies persisted for longer than the agglutinins (fig. 3).

The existence of F4 antigen in an active and accessible form in whole leptospires was shown by absorption of F4 antiserum with whole leptospires. The F4 antibodies were removed although they did not agglutinate leptospires. The combination of non-agglutinating F4 antibodies with leptospires was confirmed by indirect fluorescent-antibody reactions.

F4 antiserum was not leptospiricidal in the presence of complement unless the antiserum contained agglutinins. The role of complement in the killing of leptospires by antiserum has long been a subject of controversy. Schüffner and Mochtar (1926-27) stated that antiserum "lysed " leptospires regardless of whether complement was present, but Lawrence (1955) failed to demonstrate true lysis of leptospires by immune serum and complement. Johnson and Muschel (1966) found that leptospires were immobilised by serum only in the presence of complement, and that immobilisation correlated well with the loss of viability as determined by standard culture methods. In the present study leptospires were killed, only in the presence of complement, by agglutinin but not by F4 antibody; this effect resembled the complement-dependent immobilisation of leptospires by normal guinea-pig serum (Faine and Carter, 1968).

The effects of F4 antibody on leptospires contrast with those of anti-LPS antibody on Gram-negative enteric bacteria. Antibody to the LPS of Enterobacteriaceae produces agglutination, and the LPS polysaccharide determinants are important in serological classification schemes. The vibriocidal antibodies of immune cholera sera are directed against the polysaccharide determinants of the LPS of Vibrio cholerae (Sim and Rowley, 1970). In contrast, F4 antibody 
did not agglutinate leptospiral cells, although immunisation with $\mathrm{F} 4$ gave rise to a temporary low-level agglutinin response; it is possible that this was due to undetected antigenic impurities in the $\mathrm{F} 4$ preparation.

The capacity of immune rabbit serum to protect hamsters from acute infection with virulent homologous leptospires correlated well with the agglutinin titre. The differing results reported for other animals (Smith, 1937; Negi, Myers and Segre, 1971; Morsi, Shibley and Strother, 1973; Johnson, Bey and Auran, 1975) have been discussed elsewhere (Adler and Faine, 1978).

After immunisation with F4 antigen, rabbit antiserum with high levels of F4 antibody as measured by HA, but no detectable agglutinin, failed to protect hamsters; antisera with comparable titres of agglutinin and F4 antibodies, from rabbits immunised with whole leptospires, protected hamsters (fig. 4). On the other hand, F4 antiserum protected hamsters only if it contained agglutinins; the titres suggested that agglutinins and not F4 antibodies were responsible. The lack of in-vitro antileptospiral activity of F4 antibody suggests a further difference between F4 antigen and bacterial LPS (Weidanz, Jackson and Landy, 1964; Sim and Rowley, 1970; Diena et al., 1974).

It is not clear whether the protection afforded by agglutinin results from the activity of the immobilising antibody and complement, as seen in vitro, or from another mechanism such as opsonisation, or from both (Adler and Faine, 1977).

\section{SUMMARY}

The rabbit antibody response to leptospiral F4 antigen extracted from serovar pomona depended on the method of immunisation. Intravenous injection of whole leptospires stimulated F4 antibodies that were confined to the IgM class, but leptospires injected intramuscularly with adjuvant stimulated F4 antibodies in both the IgM and the IgG classes. Both methods of immunisation stimulated agglutinins in both the IgM and IgG classes. F4 antigen in soluble form was immunogenic when injected intradermally with adjuvant, but not when given alone. The F4 antibodies were distinct from the agglutinins in that they did not protect hamsters from acute infection with homologous leptospires, nor did they kill leptospires in vitro although they reacted with leptospires. The hamster-protective capacity of rabbit sera depended on the level of agglutinin.

This work was supported by a grant from the National Health and Medical Research Council, Canberra, Australia. The experiments involving hamsters were conducted at the National Health Institute, New Zealand, by one of the authors (B. Adler) who is grateful to the Director-General of Health for permission to publish this paper.

\section{REFERENCES}

AdLER, B. AND FAINE, S. 1976. Susceptibility of mice treated with cyclophosphamide to lethal infection with Leptospira interrogans serovar pomona. Infect. Immun., 14, 703. AdLER, B. AND FAINE, S. 1977. Host immunological mechanisms in the resistance of mice to leptospiral infection. Infect. Immun., 17, 67. 
ADLER, B. AND FAINE, S. 1978. The antibodies involved in the human immune response to leptospiral infection. J. med. Microbiol., 11, 387.

Diena, B. B., Baron, L. S., Johnson, E. M., Wallace, R. and Ashton, F. E. 1974. Role of typhoid antigens in protection and pathogenicity for mice. Infect. Immun., 9, 1102.

FaINe, S., Adler, B. AND Palit, A. 1974. Chemical, serological and biological properties of a serotype-specific polysaccharide antigen in Leptospira. Aust. J. exp. Biol. med. Sci., 52, 311.

Faine, S., Adler, B. AND Ruta, G. 1974. A mechanism of immunity to leptospirosis. Aust. J. exp. Biol. med. Sci., 52, 301.

FAINE, S. AND CARTER, J. N. 1968. Natural antibody in mammalian serum reacting with an antigen in some leptospires. J. Bact., 95, 280.

Hindle, E. AND White, P. B. 1933-34. A soluble specific substance in spirochaetes. Proc. R. Soc. $B, 114,523$.

Johnson, R. C., BEY, R. F. AND AURAN, N. E. 1975. The immunogenic properties of the outer envelope of parasitic leptospires. National Symposium on Leptospirosis, Leptospira and other Spirochaeta, Bucharest, abst.

Johnson, R. C. AND Muschel, L. H. 1966. Antileptospiral activity of serum. I. Normal and immune serum. J. Bact., 91, 1403.

LaWrence, J. J. 1955 . The lysis of leptospires by antiserum. Aust. J. exp. Biol. med. Sci., 33, 91 .

Morsi, H. M., Shibley, G. P. AND Strother, N. L. 1973. Antibody response of swine to Leptospira canicola and Leptospira icterohaemorrhagiae. Am.J. vet. Res., 34, 1253.

Negi, S. K., Myers, W. L. AND Segre, D. 1971. Antibody response of cattle to Leptospira pomona: response as measured by hemagglutination, microscopic agglutination and hamster protection tests. Am. J. vet. Res., 32, 1915.

SchüffNer, W. AND Mochtar, A. 1926-27. Versuche zur Aufteilung von Leptospirenstämmen, mit einleitenden Bemerkungen über den Verlauf von Agglutination und Lysis. Zentbl. Bakt. ParasitKde, I. Abt. Orig., 101, 405.

Sim, H. N. AND RowLEY, D. 1970. The antigens of Vibrio cholerae involved in the vibriocidal action of antibody and complement. J. infect. Dis., 121, 505.

SмIтH, J. 1937. Vaccination of guinea-pigs and human beings against leptospiral infections. J. Hyg., Camb., 37, 261.

Weidanz, W. P., JaCKSON, A. L. AND LANDY, M. 1964. Some aspects of the antibody response of rabbits to immunization with enterobacterial somatic antigens. Proc. Soc. exp. Biol. Med., 116, 832. 